\title{
Prosody signals the emergence of intentional communication in the first year of life: evidence from Catalan-babbling infants* - CORRIGENDUM
}

\author{
NÚRIA ESTEVE-GIBERT AND PILAR PRIETO
}

doi:10.ror7/So3050009r2000359, Published online by Cambridge University Press, Io August 2012.

The authors would like to correct the information given in the footnote on page 919 of this issue, concerning the research funding for this article.

*... This research has been funded by three research grants awarded by the Spanish Ministerio de Educación y Ciencia, FFI2009-07648/FILO 'The role of tonal scaling and tonal alignment in distinguishing intonational categories in Catalan and Spanish', by the Consolider-Ingenio 20ro (CSD2007-00012) Program, and by a grant awarded by the Generalitat de Catalunya to the Grup d'Estudis de Prosódia (2009SGR-70r).

Should be corrected to

*...This research has been funded by the following 5 grants: two research grants awarded by the Spanish Ministry of Science and Innovation, 'The role of tonal scaling and tonal alignment in distinguishing intonational categories in Catalan and Spanish' (FFI2009-07648/FILO), and 'Gestures, prosody and linguistic structure' (FFI20I2-3I995); a grant awarded by the Generalitat de Catalunya to the Grup d'Estudis de Prosòdia (2009SGR70I); the grant RECERCAIXA 2012 for the project 'Els precursors del llenguatge. Una guia TIC per a pares i educadors' awarded by Obra Social 'La Caixa' and the grant Consolider-Ingenio 2010 (CSD2007-000 2).

REFERENCE

Esteve-Gibert, N. \& Prieto, P. (2012). Prosody signals the emergence of intentional communication in the first year of life: evidence from Catalan-babbling infants. Fournal of Child Language 40, 9 19-43. 